\title{
Göksu Nehri Havzasının Yağış-Akış İlişkileri
}

\author{
Şahin PALTA ${ }^{1 *}$, İbrahim YURTSEVEN ${ }^{2}$, Halit AKSAY ${ }^{3}$ \\ ${ }^{1}$ Bartın Üniversitesi, Orman Fakültesi, Orman Mühendisliği Bölümü, 74100, BARTIN \\ ${ }^{2}$ İstanbul Üniversitesi-Cerrahpaşa, Orman Fakültesi, Orman Mühendisliği Bölümü, 34473, İSTANBUL \\ ${ }^{3}$ Orman Genel Müdürlüğ̈̈, 33100, MERSINN
}

\section{Öz}

Araştırmaya konu edilen Göksu havzasındaki iki adet akım gözlem istasyonu ve bir adet meteoroloji istasyonundan 2005-2014 yılları arasındaki akış ve yağış verilerinin her bir aya ait uzun dönemli ve mevsimlik verilerinde bir trendin var olup olmadığ Mann-Kendall Mertebe Korelasyonu testi ile analiz edilmiştir. Trend analizine geçmeden önce E17A020 (Hamam) ve E17A014 (Karahacılı) kod numaralı iki akım gözlem istasyonuna ait havza büyüklükleri ile debi değerleri dikkate alınarak bu iki istasyona ait su verimleri belirlenmiştir. Su verimleri ile toplam yağışın oranı olarak değerlendirilen akış katsayıları yüzdeleri her istasyon için ayrı ayrı hesaplanmıştır. Havzalardaki su veriminde meydana gelen kayıpların bir göstergesi konumunda bulunan akış katsayısı parametresi yükseldikçe havzadaki toplam su kaybının az olduğu, düştükçe su kaybının fazlalaştığı ya da suyun toprakta depo halinde bulunduğu ya da doğal akışın baraj vb. yapay etkenlerle sınırlandığı sonucuna varılabilmektedir. Yıllık toplam akış ve yağış değerleri göz önüne alındığında E17A020 nolu havzanın akış katsayısı \%43.49, E17A014 kod numaralı akım gözlem istasyonu için ise \%41.28 olarak hesaplanmıştır. Havzadaki yağış-akış ilişkisini tespit etmek için her 12 ay ayrı ayrı değerlendirilerek yapılan trend analizinde E17A020 istasyonunda tüm aylarda trendin var olmadığı, E17A014 istasyonunda ise Temmuz ve Eylül akışlarında bir artış olduğu görülmektedir. Diğer aylarda ise bu istasyon için herhangi bir eğilim bulunamamıştır. Her iki istasyonda da dört mevsim ayrı ayrı değerlendirildiğinde uzun dönemli zaman serilerinde sadece E17A014 istasyonuna ait yaz mevsimi yağışlarında artış görüldüğü diğer mevsimlerde ise herhangi bir artış veya azalış trendi bulunmadığı görülmektedir. Yağış trendinde ay ve mevsimde hiç bir trendin varlığının görülmemesi son yıllarda yaz aylarındaki akarsu akışlarında yapay baraj ve bend gibi depolama alanlarından suyun beslemesinin arttı̆̆ı çıkarımı elde edilmiştir.

Anahtar Kelimeler: Yağış, akış, Göksu Nehri Havzası, su verimi.

\section{Rainfall-Runoff Interactions of Göksu River Basin}

\section{Abstract}

The existence of any trend for the monthly and seasonal rainfall and runoff data between 2005-2014 acquired from the two runoff gauge station and one meteorological station at the Göksu River basin in Mersin province, were analyzed based on the Mann-Kendall Rank Correlation test. Prior to the trend analysis, initially, water yields were obtained dependent upon the basin sizes and flow rate data belonging to the runoff stations with the codes of E17A020 (Hamam) and E17A014 (Karahacil1). Then, flow coefficient percentages were determined for each station, based on the water yields and total rainfall ratios. The increase in the flow coefficient parameter that is an indicator of the water yield deficiency, implies the low total water deficiency within basin whereas the decrease emphasizes the much total water deficiency or the water is trapped as soil moisture or the natural flow is restricted by any structural means such as dams and etc. Considering the annual total flow and rainfall data, the runoff coefficient of the station with the code of E17A020 was $43.49 \%$ while it was $41.28 \%$ for the E17A014. In order to determine the rainfall-runoff interactions within the basin, the trend analyses for each 12 months revealed the inexistence of trend for the all months at the E17A020 station whereas revealed the increase for the July and September at the E17A014. On the other hand, no trend was determined for the other months. When the four seasons were separately evaluated, the increase in the summer season rainfall for long-term time series was observed only at the E17A014 station, yet it did not occur for the other seasons. According to the rainfall trend for the E17A020 station, it was concluded that the inexistence of any monthly and seasonal trend may be due to the artificial storage structures such as dams and etc.

Keywords: Rainfall, runoff, Göksu River Basin, water yield. 


\section{Giriş}

Canlıların hayatlarını devam ettirebilmeleri, özellikle de ekstrem ekosistem koşullarında, yaşadıkları şartlara karşı gösterebilecekleri toleransa bağlıdır (Odum ve Barrett, 1971). Ekosistem içerisindeki optimum koşulların değişimi doğal veya antropojenik etkiler ile meydana gelebilmektedir. Bu koşulların belki de en önemlisi iklim değișikliğinin ekosistem üzerinde meydana getirdiği değişimlerdir. Bölgesel ve yerel ölçekte iklim değişikliğinin en belirgin izleri iklim parametreleri ve hidrolojik kaynaklar üzerinde görülebilmektedir (Nijssen vd., 2001). İklim değişikliğinin iklim parametreleri üzerinde en etkili olanları ise yağış ve sıcaklık parametreleridir (Hurrell, 1995; Babalık vd., 2018). Akarsular ise bir havzadaki su verimini gösteren önemli kaynaklardır. Bir havzadaki yağış ve akış ilişkisi havzanın hidrolojik durumunu ve iklim değişikliğine karşı davranışını saptamada etkili olabilmektedir (Arnell, 1999). İklim değişikliği ile ilgili olarak yapılan çalışmalarda en etkili unsur geçmişten günümüze kadar belirli aralıklar ile ilgili parametrelerin ölçümleri neticesinde elde edilen veri setleridir. Bu veri setlerini bu sebeple bir zaman serisi olarak düşünüp iklim değișikliği çalışmalarında bu zaman serileri üzerine odaklanılması gerekmektedir. Bu zaman serisi ileriye yönelik projeksiyonların yapılmasını da gerçekleştirebilecektir. İklim değişikliği çalışmalarında bölgesel ölçekte iklim değiş̧ikliği izlemelerinin yapılabilmesi için uzun dönemli zaman serisi analizleri etkili olmaktadır.

İklim değişikliği özellikle sanayi devriminden sonra fosil yakıt kullanımındaki artışla beraber atmosfere salınan sera gazı miktarındaki artış ile etkisini artırmıştır (Rustad vd., 2000). Farklı sera gazları içerisinde özellikle karbondioksit $\left(\mathrm{CO}_{2}\right)$ konsantrasyonundaki artış yer kürenin üzerindeki atmosfer tabakasında hızla birikerek yeryüzünün ısınmasına yol açtığı görülmektedir (Manabe ve Wetherald, 1980). Yapılan bazı araştırmalar yeryüzündeki çok küçük sıcaklık farklılıklarının bile atmosfer ile olan etkileşimini büyük ölçüde sağlayan bir iklim parametresi olan yağışların da dinamiklerinde değişime sebebiyet verdiği görülmüştür (Meinshausen vd., 2009). Sıcaklığın doğrudan, yağışın ise dolaylı olarak bu iklim değiş̧ikliğinden etkilenmesi yeryüzündeki koşulları ve burada yaşayan canlı topluluklarının popülasyon ve göç durumlarını da değiştirebilmektedir. Yağış miktarındaki azalmalar, bölgenin su kaynaklarını olumsuz etkileyerek burada yaşayan canlı topluluklarının popülasyonları üzerinde farklılıklara neden olmaktadır. Meydana gelen su azalmasına karşı adaptasyon yeteneği fazla olan canlı gruplarının popülasyonda baskın konuma gelebilmektedir. Dolayısıyla canlılığın yer yüzeyinde devamlılığı ve optimizasyonu iklim parametreleri (özellikle yağış ve sıcaklık) ile su kaynakları durumunun belirleyici rol oynadığı görülmektedir (Odom ve Barrett, 2008).

Bilindiği gibi yağış ve akış su döngüsünü yönlendiren iki temel unsur olarak karşımıza çıkmaktadır. Bu iki unsur aynı zamanda suyun doğada bulunmasını ve var oluş biçimini tetikleyen bir mekanizma oluşturmaktadır. Küresel ölçekte bakıldığında suyun doğada hiçbir zaman kaybolmadığı sürekli döngüsel bir biçimde sistemde yer aldığ 1 görülmektedir. Ancak bölgesel ölçekte bakıldığında bazı bölgelerde özellikle sıcaklığın da etkisi ile su kaynaklarının diğer bölgelere nazaran daha az biçimde yer aldığı görülebilmektedir. Doğadaki suyun kaynağı yine doğadan meydana gelen buharlaşmalardır ancak doygun su buharına sahip hava kütleleri küresel cephe hareketleri ile diğer su kıtlı̆̆ı çeken bölgelere taşınamaması ya da orografik etkilerle bu hava kütlelerinden faydalanılamaması, kuraklığı bu bölgelerde meydana gelmesinde etken rol oynamaktadır. Ekvator bölgesine yakın birçok ülkede su kıtlığının baş gösterdiği görülebilmektedir. Özellikle iklim değişikliği çalışmaları ekvator bölgesi ile sınırlı gösterilen bu kurak alanların daha da kuzeye ve güneye yayılarak kuraklık etkisinin bu bölgelerde de görülebilmesinin yakın gelecekte mümkün olacağını savunmaktadırlar (Schipper ve Pelling, 2006; Stringer vd., 2009). Ülkemizde böyle bir riskle karşı karşıya kalan bölgelerimiz de bulunmaktadır. Özellikle Akdeniz ve Güneydoğu Anadolu bölgesi ileride iklim değişikliğinin daha fazla hissedilebileceği risk potansiyeli yüksek bölgeleri oluşturmaktadır. Bu bölgelerde yapılacak bölgesel uzun dönemli iklimsel ve hidrolojik çalışmalar bölgenin iklim değişikliğine bünyesinde mevcut durumun ve potansiyelin belirlenmesinde etkili olabilecektir.

İklim değişikliği ile mücadele uyum ve azaltım başlıkları altında değerlendirilmektedir (Black vd., 2011). Yeşil alanların artırılması iklim değişikliği ile mücadelede azaltım başlığı altında değerlendirilmektedir (Spittlehouse ve Stewart, 2003). Orman alanları CO2 yutağı niteliğini taşımalarından dolayı iklim değişikliği ile mücadelede ön sıralarda yer almaktadır. Ormanlar ayrıca yapısal özelliklerinden dolayı hidrolojik düzenleyici olarak da görev yapmaktadır (Özhan, 2004). Orman toprakları dökülen bitkisel artıkların meydana getirdiği ölü örtü tabakası nedeniyle topraklara yüksek organik madde kazandırmalarının yanı sıra bu tabaka kendi ağırlığının yaklaşık 4-5 katı kadar suyu tutup zararsız biçimde orman toprağına kazandırmaktadır (Balcı, 1996). Dolayısıyla orman toprakları bir su deposu işlevi yaparak akarsuların yıl boyunca daha düzenli ve temiz biçimde akmalarını sağlarlar. Aynı zamanda intersepsiyon adı verilen ve yağmurun bitkinin gövde üstü organlarında tutulup buradan buharlaşma ile atmosfere geri gönderimi sağlanarak fazla suyun da toprağa kazandırılmasının önüne geçilmiş olmaktadır. Böylelikle ormanlar sel ve taşkın oluşumu riskini de azaltmaktadırlar. Ayrıca kökleri vasıtasıyla toprak suyunu kullanarak toprakta hidrolojik düzenleme işlevini de 
gerçekleştirmiş olmaktadır. Dolayısıyla ormanlar iklim değişikliği karşısında (örneğin ekstrem akarsu koşullarında) meydana gelebilecek zararlarda sigorta işlevi görmektedirler (Canadell ve Raupach, 2008). Bu husus hava içerisindeki yağış- akış ilişkilerinde de vejetasyonun etkin olduğunu göstermektedir.

Araştırmanın amacı, Göksu havzasındaki akış ve yağışta uzun yıllar yapılan ölçümler dikkate alınarak bir artma, azalma ya da herhangi bir değişim olup olmadığının saptanması, iklim değişikliği konusunda havzanın durumunun belirlenmesidir. Bu amaçla, her bir ay ve mevsime ait uzun dönemli akış ve yağış verileri trend analizine tabi tutularak ilgili ay ve mevsimde bir eğilim araştırması gerçekleştirilmiştir. DSİ Genel Müdürlüğüne ait E17A020 (Hamam) ve E17A014 (Karahacılı) kod numaralı iki adet akım gözlem istasyonunun 2005-2014 yılları arasındaki günlük toplam akış değerleri (debi değerleri) değerlendirme kapsamına alınmıştır. Yine yağış verileri için havzadaki bir meteoroloji istasyonundan 2005-2014 y1llarına ait günlük toplam yağıŞ verileri değerlendirilmiştir.

\section{Materyal ve Metot}

\subsection{Materyal}

Araştırmada yağış akış verilerinin analiz edilmesi için tipik Akdeniz iklimi etkilerinin hüküm sürdüğü ve sınırlarının büyük çoğunlukla Mersin ili sınırları içerisinde var olan Göksu havzası dikkate alınmıştır (Şekil 1). Havza, Göksu ırmağı ve yan kollarının oluşturduğu yaklaşık $10000 \mathrm{~km}^{2}$ ’lik bir alandan oluşmakta olup Mersin ilinin Silifke ilçesi yakınlarından Akdeniz’e sularını boşaltmaktadır. Göksu ırmağının denize yakın kısımlarındaki Göksu deltası bir çok canlı türüne ev sahipliği yapan ve özel çevre koruma yasaları ile korunmakta olan bir alandır. Delta içerisinde Akdeniz’e yakın kısımlarda Paradeniz ve Akgöl adında iki adet lagün de bulunmaktadır. Bu lagünlerde özellikle deniz ve akarsu alanlarında etkileşimde bulunan balık türleri de bulunmaktadır. Dolayısıyla havza içerisinde akan akarsular özellikle su ve karasal ortamdaki flora ve fauna topluluklarının yaşamlarını devam ettirebilmeleri açısından elzem öneme sahip olmaktadır. Özellikle yaklaşık 15000 ha alan kaplayan Göksu deltasına akarsu ile gelen su miktarında bir azalma durumunda burada yaşayan ya da bir göç sırasında konaklama yapabilecek canlı türlerini ve popülasyon durumlarını etkileyebilecektir. Özellikle havza içerisindeki su kaynaklarından olan ve havzanın can damarını teşkil eden Göksu ırmağının su veriminin ve havzaya düşen yağıș miktarının uzun dönemli analizi havzanın iklim değişikliği konusundaki durumunu belirlemede etkili olabilmektedir. Ayrıca alınabilecek önlemlerin çeşidi ve yoğunluğu da böyle bir araştırmanın gerekliliğini ön plana çıkarmaktadır.

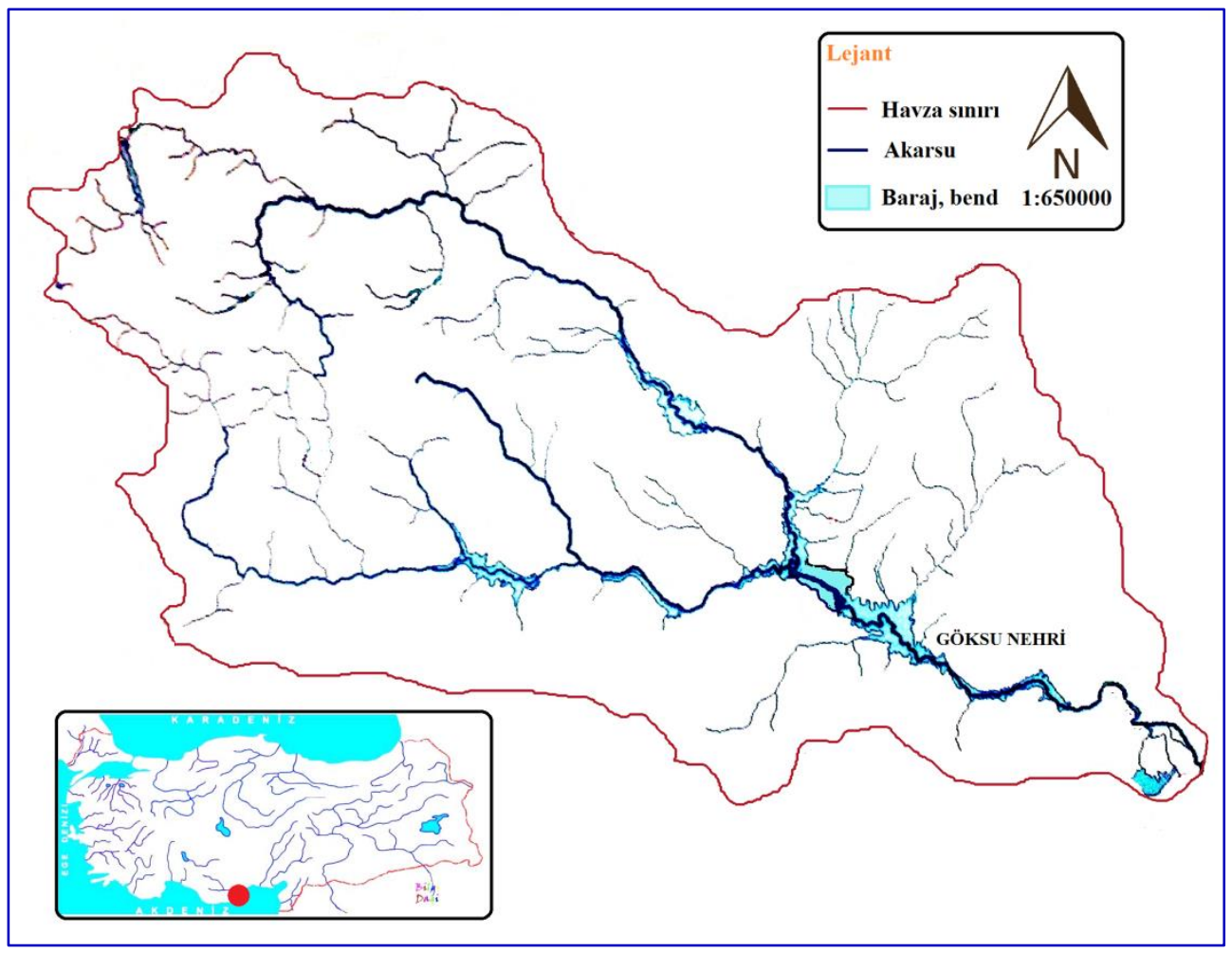

Şekil 1. Göksu nehri havzasının görünümü. 
Göksu havzası içerisinde bulunan delta nedeniyle ülkemiz adına önemli biyoçeşitlilik alanlarından birisini oluşturmaktadır. Bu alan özellikle nadir ve nesli tükenme tehlikesine düşmüş kuşların ve bunların bağımlı olarak yaşadığı bitki türlerinin bir arada bulunduğu önemli bir sulak alan ekosistemidir. Özellikle flora ve faunanın yaşam evrelerinin optimum biçimdeki devamlılığı bu delta ya da genel olarak havzayı besleyen su kaynaklarının varlığı ve havzanın akış üretme potansiyeli ile yakından ilişkilidir. Havzanın ana akarsu kolunu oluşturan Göksu nehri Seyhan ve Ceyhan nehirlerinden sonra Akdeniz'e dökülen önemli bir su kaynağı olup uzunluğu 260 km'dir. Göksu havzasının toplam alanı yaklaşık $10.400 \mathrm{~km}^{2}$ 'dir. Göksu nehri, deltanın ortasından geçmekte olup deltanın can damarlarından birisini oluşturmaktadır. Göksu deltasının tüm sulak alan yüzeylerinin toplamı ise yaklaşık 1.954 ha'dır.

\subsection{Veri Seti}

Araştırmada Göksu havzası üzerindeki iki adet akım gözlem istasyonu ve bir adet meteoroloji istasyonuna ait günlük akış ve yağış verileri kullanılmıştır. Akım gözlem istasyonları DSİ Genel Müdürlüğüne ait E17A020 (Hamam) ve E17A014 (Karahacılı) istasyonlarıdır. E17A020 (Hamam) istasyonunun yağış toplama alanı 4.304 $\mathrm{km}^{2}$ 'dir. E17A014 (Karahacılı) istasyonunun ise $10.065 \mathrm{~km}^{2}$ dir. E17A014 istasyonunun havzanın çıkış noktasında yer aldığı görülmektedir. E17A020 istasyonu ise havzanın yaklaşık olarak yarısını drene ettiği anlaşılabilmektedir. Dolayısıyla akış verimi olarak havza genelini E17A014 istasyonu temsil etmektedir. Araştırmada her iki istasyona ait akış ve meteoroloji istasyonuna ait yağış verileri 2005 yılı itibariyle günlük değerler olarak dikkate alınmıştır. DSİ Genel Müdürlüğü'nden alınan akış verileri debi olarak hesaplanmış olup birimi $\mathrm{m}^{3} / \mathrm{sn}$ olarak verildiği görülmektedir. Araştırmada akım gözlem istasyonlarının debi değerleri bu istasyonların drene ettiği alanlar da göz önüne alınarak su verimi değerlerine $(\mathrm{mm})$ dönüştürülmesi yoluna gidilmiştir. Çünkü Meteoroloji istasyonlarından alınan yağış verileri de mm cinsinden ifade edilmektedir ve kıyaslama yapılırken akış ve yağış birimlerin benzer nitelikte bulunmasına dikkate edilmiştir. İstasyonların debi değerlerinin su verimi değerlerine dönüştürülmesi aşağıdaki eşitlik ile elde edilmiştir.

Su verimi $(\mathrm{mm})=\frac{Q_{\text {ort }} x t}{A}$

Eşitlikte Q ort istasyona ait ortalama debi değerini, t dikkate alınan zamanı ve A drene edilen alanı ifade etmektedir.

\subsection{Metot}

Göksu havzası su üretme potansiyeli, havzanın çıkış noktasında bulunan delta nedeniyle hayati öneme sahiptir. Çünkü Göksu deltasının biyoçeşitliliği ve türlerin neslinin tehlikeye uğramaması için devamlı su kaynağı ile beslenmesi gerekmektedir. İşte bu su kaynağı havzanın can damarı konumunda bulunan Göksu nehri ile sağlanmaktadır. Araştırmada Göksu havzası akış değerleri, havzanın ortasına yakın bir noktada seçilen bir akım gözlem istasyonu ile havzanın çıkış noktasına yakın bir noktada seçilen bir akım gözlem istasyonunun 2005 yılından 2014 yılına kadar olana günlük debi değerleri alınmıştır. Öncelikle akım gözlem istasyonlarının su toplama alanları da dikkate alınarak debi değerleri su verimi değerlerine dönüştürülmüştür. Böylelikle mm cinsinden su verimi değerleri, $\mathrm{mm}$ biriminde ifade edilen yă̆ģ̧ değerleri ile aynı birim cinsinden karşılaştırılmıştır. Metodun ana yaklaşımı Göksu havzasındaki yağış ve akış ilişkilerinin belirlenmesidir. Bu amaçla öncelikle veri setinin uzun dönemli eğilimlerinin belirlenmesi havzanın gelecekteki yağış ve akış durumunu tahmin etmede önemli bir altyapı oluşturmasına katkı sağlayacaktır. Analizde günlük su verimleri aylar ve mevsimler bazında değerlendirilmiştir. Diğer bir deyişle her ay ve mevsime ait uzun dönemli akış ve yağış verilerinin trend analizi gerçekleştirilmiştir. Araştırmada trend analizi dışında yağış ve akış verilerinin grafiksel ve istatistiksel olarak analizleri de gerçekleştirilmiştir. Ayrıca, özellikle havzaların akış üretme potansiyelini gösteren akış katsayıları da istasyonlar dışında aylar ve mevsimler dikkate alınarak ayrı ayrı hesaplanmıştır.

\subsubsection{Regresyon analizi}

Regresyon analizi, bağımlı ya da bağımsız değişkenler arasındaki ilişkiyi ve bu ilişkinin performansını istatistiksel olarak analiz etmeye yarayan bir metottur. Bu metotta bağımsız değişkenler üzerinden bağımlı değişkenin değeri bir eşitlik yardımıyla belirlenmektedir. $Y=a+b * X$ olarak ifade edilen basit doğrusal regresyon eşitliğinde $\mathrm{Y}$ değerleri bağımlı değişken, $\mathrm{X}$ değerleri ise bağımsız değişken olarak eşitlikte yerlerini almaktadır. Eşitlikte a değeri doğrunun $\mathrm{Y}$ eksenini kestiği değer olarak başlangıç değerini, b ise doğrunun eğimi olarak değerlendirilmiş olup x'deki 1 birim değişmeye karşılık y'deki değişim miktarını göstermektedir (Yurtseven, 
2016). Regresyon analizinin performansı korelasyon katsayısı ile belirlenebilmektedir. Korelasyon katsayıs aşağıdaki formüle göre hesaplanmaktadır;

$$
r=\frac{\sum(x y)-\left(\sum x\right)\left(\sum y\right) / n}{\sqrt{\left(\sum x^{2}-\left(\sum x\right)^{2} / n\right)\left(\sum y^{2}-\left(\sum y\right)^{2} / n\right)}}
$$

Eşitlikte $\mathrm{x}$ bağımlı, y bağımsız değişkenleri ve $\mathrm{n}$ örnek sayısını temsil etmektedir. Korelasyon katsayısı 0 ve 1 değerleri arasında değişmekte olup değerlerin 1'e yaklaşması durumunda istatistiksel ilişkinin de kuvvetleneceği anlamına gelecektir. Araştırmada her akım istasyonunun yağış ve akış verileri regresyon analizine tabi tutularak analizleri gerçekleştirilmiştir. Havzada her yağış verisine akış verisinin benzer ölçüde tepki vermesi diğer bir deyişle havzanın hidrolojik davranışının/cevabının yağışa uyumlu biçimde olması koşulunda yağış ve akış ilişkilerindeki korelasyon katsayısının da yükseleceği anlamı taşımaktadır.

\subsubsection{Akış Katsayısı}

Akış katsayısı havzadaki akışın havzaya düşen yağışa oranının yüzde cinsinden ifade edilmesidir. Bir havzanın yağış girdisine karşı akış tepkisinin ne olduğu diğer bir deyişle havzanın akış üretme potansiyelinin ne düzeyde olduğunu belirlemeye yönelik önemli bir havza indikatör parametresidir. Bilindiği gibi özellikle açık alanlardan meydana gelebilen buharlaşma dışında bitki örtüsünün yağış sularını tutarak atmosfere geri gönderdiği intersepsiyon olgusu da havzadaki akış miktarı üzerinde belirleyici rol oynayabilmektedir (Özhan, 2004). Akış katsayısı aşağıdaki eşitlik ile hesaplanmaktadır:

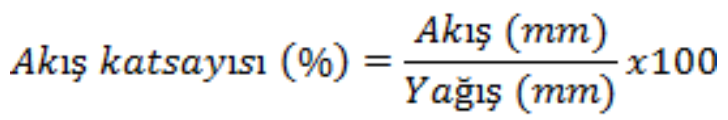

Araştırmada istasyonlar arasında da akış katsayıları arasındaki fark belirlenmiş olup istasyonlara ait yağış akış ilişkisinin bu katsayı üzerinden değerlendirmesi yapılmıştır.

\subsubsection{Mann-Kendall Mertebe Korelasyonu}

Mann-Kendall trend analizi havzanın özellikle iklim değişikliğine karşı bölgesel ölçekteki mevcut durumunun analiz edilmesinde çok etkili olmaktadır. Özellikle uzun dönemli yağış ve akış (su verimi) değerlerine bağlı olarak bir trendin varlığı ve bunun istatistiksel güven düzeyini (\%95) karşılayıp karşılamadığı Mann-Kendall Mertebe Korelasyonu Testi yardımıyla belirlenebilmektedir. Araştırmada her iki akım gözlem istasyonuna ait su verimi $(\mathrm{mm})$ değerleri ile havza içerisindeki meteoroloji istasyonuna ait yağış miktarı $(\mathrm{mm})$ değerleri her ay ve mevsim ayrı ayrı olacak şekilde trend analizine tabi tutulmuştur. Yağış verilerine ait serilerin belirli bir zaman periyodu içerisinde eğilimlerini (trendini) ve bu eğilimlerin şiddetini saptamak için parametrik olmayan MannKendall korelasyon testi sıklıkla kullanılmaktadır. Hidrolojik ve meteorolojik araştırmalarda eğilimin yönünün (artma-azalma ya da değişmeme) istatistiksel açıdan önemli olup olmadığını test etmede başvurulan bir yöntemdir (Yurtseven ve Serengil, 2016).

$\mathrm{Bu}$ testte gerçek veri yerine verinin seri içerisindeki sıralaması $\left(\mathrm{y}_{\mathrm{i}}\right)$ kullanılmaktadır. Testte her $\mathrm{y}_{\mathrm{i}}$ için önceki sıradan büyük olanları sayılarak $n_{i}$ gibi bir sayı tanımlanır. $n_{i}$ lerin toplamları ile test istatistiği $t$ bulunur (Sneyers 1990; Yurtseven ve Serengil, 2016).

$t=\sum_{i=1}^{n} n_{i}$

Bunun ortalama varyansı sırasıyla;

$$
E(t)=\frac{n(n-1)}{4} \text { ve var } t=\frac{n(n-1)(2 n+5)}{72}
$$

eşitlikleriyle ifade edilmektedir. Önemli bir çıktı konumunda bulunan Mann-Kendall test istatistiği değeri u(t) ise aşağıdaki eşitlik ile hesaplanabilmektedir. 
$u(t)=\frac{[t-E(t)]}{\sqrt{\text { vart }}}$

İstatistiksel olarak zamanla bir değişim olmadığı durumlarda u (t)'nin sıfıra yakın değerler aldığı görülmektedir. Şayet $\mathrm{u}(\mathrm{t})$ büyük değerler alması durumunda zaman serisinde bir değişimin olduğu belirlenmektedir. u(t)'nin $\pm 1,96$ 'ya ulaşması trendin önemlilik seviyesinin \%95'lere ulaştığını göstermektedir (Toros 2012; Yurtseven ve Serengil, 2016).

\subsubsection{Pettitt Testi}

Pettitt testi, trendin değişim noktasını belirlemek için 1979 yılında araştırmacı Pettitt tarafından geliştirilmiştir (Pettitt, 1979). Pettitt testinde sıfır hipotezi serinin bağımsız ve rastgele dağılımının olduğunu alternatif hipotez ise ani bir değişiminin olduğunu açıklamaktadır. Pettitt (1979)'a göre $Y_{1}, \ldots, Y_{n}$ değerleri testte $r_{1}, \ldots, r_{n}$ olarak sıralanmaktadır. Değişim noktası ise $\mathrm{X}_{\mathrm{k}}$ 'nın mutlak maksimum değeridir ve bu değer aşağıdaki formül ile hesaplanmaktadır.

$X_{k}=2 \sum_{i=1}^{k} r_{i}-k(n+1) \quad k=1,2,3,4, \ldots, n$

Eşitlik sonucu $\mathrm{X}_{\mathrm{k}}$ değeri grafiksel olarak çizilebilir. $\mathrm{X}_{\mathrm{k}}$ 'nın mutlak maksimum değeri $\left(\mathrm{X}_{\mathrm{E}}\right)$ aşağıdaki gibi belirtilmiştir,

$X_{E}=\max _{1 \leq k \leq n}\left|X_{k}\right|$

Monte Carlo simülasyonu kullanılarak hesaplanan $p$ değeri 0.05 değerinden küçük çıkması koşulunda sıfır hipotezi reddedilerek alternatif hipotez kabul edilmektedir (Yurtseven ve Serengil, 2016).

\section{Bulgular ve Tartışma}

\subsection{Grafiksel Analiz Bulguları}

Araştırmada öncelikle akış ve yağış verilerinin grafiksel değerlendirmeleri gerçekleştirilmiştir. Bu amaçla her iki akım gözlem istasyonuna ait su verimi değerleri ile meteoroloji istasyonuna ait yağış verileri bir grafik üzerinde gösterimi aşağıdaki gibi olmaktadır (Şekil 2).

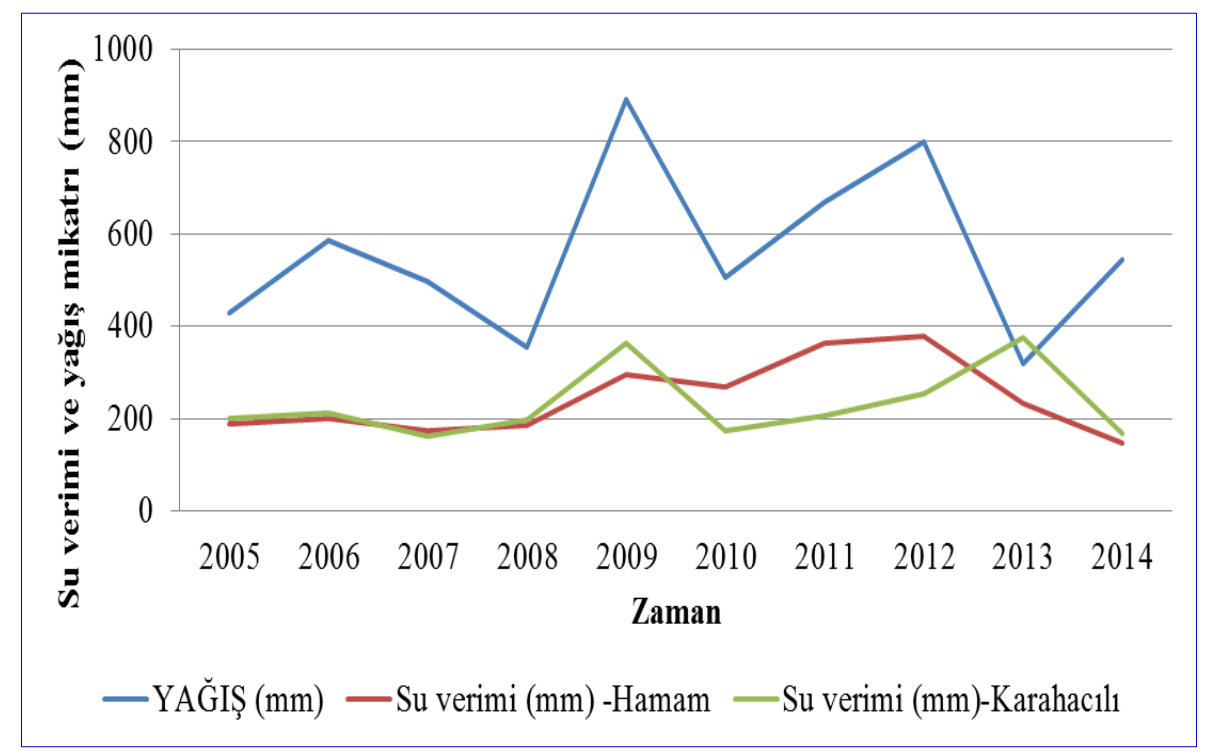

Şekil 2. Yıllık yağış ve su verimi grafiği. 
Şekil 2 'ye göre E17A020 (Hamam) ve E17A014 (Karahacılı) akım gözlem istasyonlarına göre elde edilen yıllık eğrilerin özellikle 2008 yılına kadar birbirine çok yakın seyrettikleri 2008 yılından sonra ise aylık su verimi eğrilerinin birbirine benzerliklerinin kaybolduğu görülebilmektedir. Grafiğe bakıldığında yağış eğrisine hidrolojik tepkisellik (duyarlılık) bakımından en yakın istasyonun E17A020 (Hamam) istasyonu olduğu bulunmuştur. Diğer bir deyişle yağış akış ilişkilerinde akım gözlem istasyonlarının grafiksel hidrolojik tepkiselliği değerlendirildiğinde E17A020 (Hamam) akım gözlem istasyonunun diğer istasyona göre hidrolojik duyarlılığının daha fazla olduğu görülebilmektedir. Yağış verilerinin özellikle akış verilerine göre iki katı ve daha yüksek seviyelerde seyretmesinden dolayı akış katsayılarının 0,5'ten daha düşük olabileceği düşünülmektedir.

Yukarıdaki yıllık grafiksel değerlendirme dışında mevsimlik grafiksel değerlendirme de yapılmıştır. Bu amaçla ilkbahar mevsimi Mart, Nisan ve Mayıs ayları, yaz mevsimi Haziran, Temmuz ve Ağustos ayları, sonbahar mevsimi Eylül, Ekim ve Kasım aylarını ve kış mevsimi için Aralık, Ocak ve Şubat ayları dikkate alınmıştır. Akış ve yağış verisi de mevsimler içerisinde bulunan ilgili ayların toplam değerleri üzerinden hesaplanmıştır.

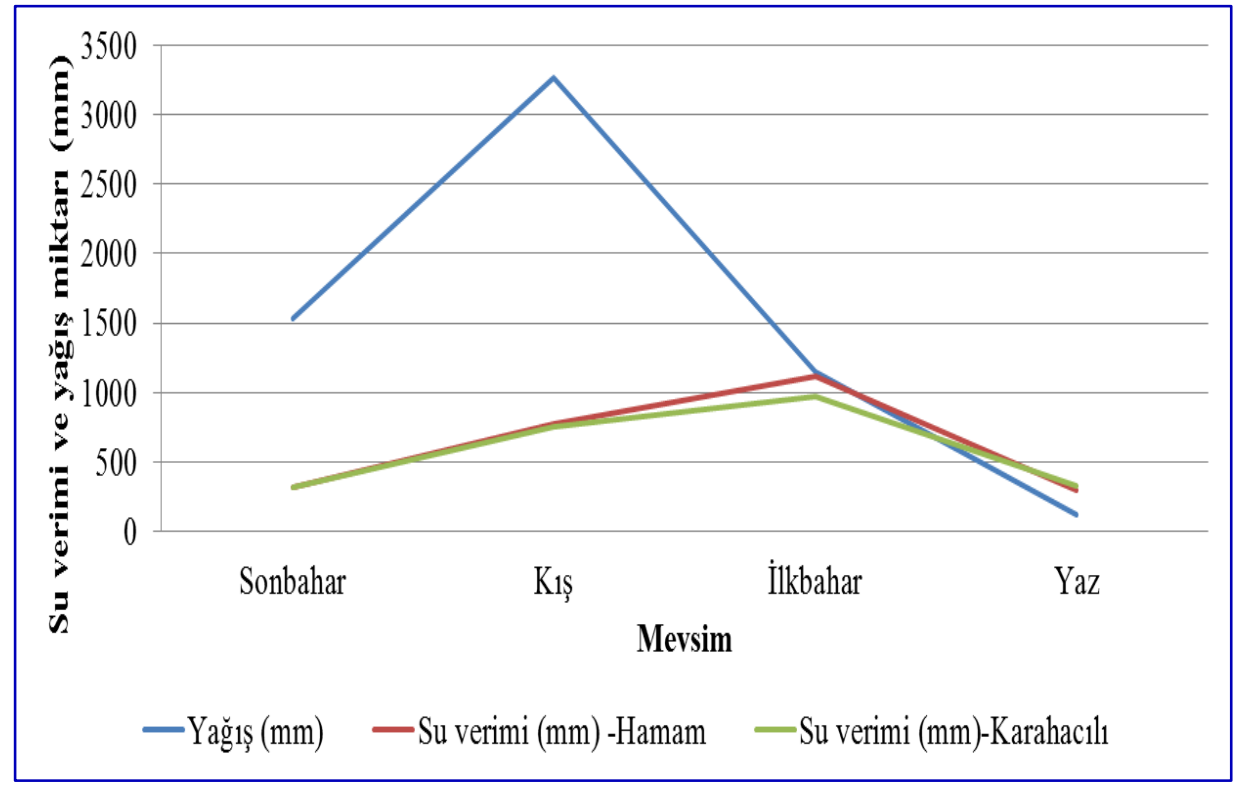

Şekil 3. Mevsimlik yağış ve su verimi grafiği.

Yukarıdaki Şekil 3 'te görülen mevsimlik akıș ve yağış ilișkisi değerlendirildiğinde, akış ve yağıș miktarlarına ait eğrilerin özellikle ilkbahar ve yaz mevsiminde birbirine oldukça yaklaştıkları görülebilmektedir. Bu husus bu mevsimlerde düşen yağışın büyük çoğunluğunun akışa geçtiğini göstermektedir. Havzada bu mevsimlerde benzer miktarda yağış ve akış miktarının görülmesi havzada hidrolojik duyarlılığın bu mevsimlerde daha da yükseldiğini ve bu mevsimlerde diğer mevsimlere göre akış miktarında yağış miktarı ile kıyaslandığında bir kaybın yaşanmadığı ya da çok az miktarda yaşandığı düşünülmektedir.

\subsection{Regresyon Analizi Bulguları}

Yağ1ş-akış ilişkilerinin analizinde kullanılan bir diğer yöntem ise regresyon analizi ve bu analize bağlı olarak geliştirilen korelasyon katsayılarıdır. Her bir akım gözlem istasyonunun yağış verisi ile olan istatistiksel ilişkisi aşağıdaki şekil üzerinde gösterilmiştir (Şekil 4). 


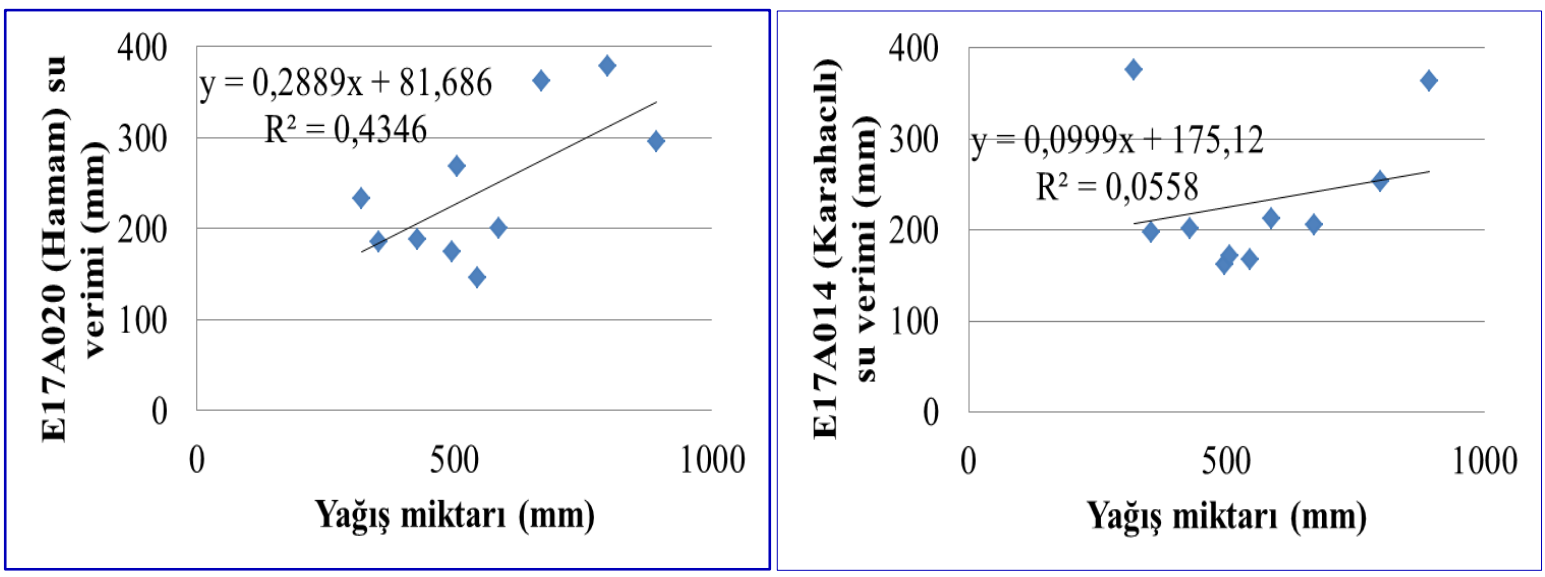

Şekil 4. Farklı akım gözlem istasyonlarındaki yıllık su verimi (akış) değerlerinin yağış miktarı ile olan regresyon analizi grafiği.

Şekil 4 değerlendirildiğinde özellikle Hamam akım gözlem istasyonunun diğer akım gözlem istasyonuna göre aylık su verimi ile yağışın istatistiksel anlamda daha kuvvetli bir ilişkide bulunduğu görülebilmektedir.

\subsection{Akış Katsayısı Bulguları}

Akım gözlem istasyonlarının yıllık su verimleri ve meteoroloji istasyonunun yıllık yağış miktarı arasında akış katsayıları arasında da farklılıklar oluştuğu yukarıdaki grafiklerden anlaşılabilmektedir. E17A020 (Hamam) akım gözlem istasyonuna ait akış katsayısı \%43.49 olarak bulunmuştur. E17A014 (Karahacılı) istasyonunda ise bu değer \%41.28 olarak elde edilmiştir. Dolayısıyla yıllık bazda değerlendirildiğinde aynı miktarda yağış durumu göz önüne alındığında E17A020 akım gözlem istasyonu diğer istasyona göre daha fazla suyu drene ettiği görülebilmektedir. Akış katsayıları arasındaki bu farklılıktan, E17A014 (Karahacılı) istasyonuna ait yağış toplama alanında diğer istasyonun yağış toplama alanına göre daha fazla buharlaşma, intersepsiyon ve transpirasyon gibi kayıpların yaşandığını ya da suyun toprakta daha fazla depolandığı düşünülmektedir. E17A014 (Karahacılı) istasyonu havzanın çıkış noktasına yakın bir noktada bulunmaktadır. Bu nedenle, Göksu havzasının akış katsayısı da bu istasyonun akış katsayısı olarak alınabilmektir. Dolayısıyla Göksu havzası için elde edilen \% 41.28 akış katsayısı yüzdesi ile havzaya düşen her 100 birimlik yağışın yaklaşık 41'inin akışa geçtiği söylenebilmektedir. Özellikle ilkbahar ve yaz mevsimlerindeki akış katsayısı değerlerinin diğer iki mevsime göre daha yüksek çıktığı görülebilmektedir. Ancak bunun miktarsal analizi gerçekleştirilip aşağıdaki tabloda gösterilmektedir.

Tablo 1. Mevsimlik yağış, su verimi ve akış katsayısı tablosu.

\begin{tabular}{lcccc}
\hline & Sonbahar & Kış & İlkbahar & Yaz \\
\hline Yağış (mm) & 1531,70 & 3264,70 & 1144,20 & 117,70 \\
E17A020 Su verimi (mm) & 313,24 & 769,04 & 1114,21 & 292,73 \\
E17A014 Su verimi (mm) & 317,52 & 748,82 & 968,94 & 327,12 \\
E17A020 Akış katsayısı (\%) & 20,45 & 23,56 & 97,38 & $>100$ \\
E17A014 Akış katsayısı (\%) & 20,73 & 22,94 & 84,68 & $>100$ \\
\hline
\end{tabular}

Tablo 1 incelendiğinde özellikle yaz mevsiminde akış katsayısının \% 100’ün üzerinde olduğu görülebilmektedir. $\mathrm{Bu}$ durum akış dinamiklerinde düşen yağıştan çok toprakta depo edilen su miktarının ya da baraj veya bendlerde depo edilen suyun yazın tarımsal sulamalar maksadıyla kullanılmasının etkili olduğu düşünülmektedir. Çünkü yazın düşen yağış miktarı oluşan akış miktarının çok altında olduğu görülmektedir. Havzaya girdi olarak kabul edilen yağışın üzerinde bir akış oluşabilmesinin en gerçekçi açıklaması havzanın bu mevsimde havzadaki doğal (toprak) veya yapay (baraj, bend vb.) su depolarındaki suyun kullanılmasıdır. Yaz mevsimi dışında ilkbahar mevsiminde de havza için kuraklık sinyallerinin başladığı görülmektedir. Özellikle havzaya düşen yağış miktarına yakın miktarda akışın gerçekleşmesi akış katsayısının bu mevsimde de yüksek çıkmasına yol açmıştır. Geç ilkbahar ve yaz mevsimlerinde akış katsayısının düşmeyerek yüksek değerlerde oluşması havzanın çıkış 
(mansap) noktasına yakın alanlarda konumlanan deltanın canlılığının sürdürülebilmesi için oldukça önemli önemli görülmektedir.

\subsection{Mann-Kendall Mertebe Korelasyonu Testi Bulguları}

Bölgesel olarak iklim değişikliği çalışmaları ile birlikte havzadaki yağış ve akış miktarlarının uzun dönemli analizlerinde trend (eğilim) analizinin önemli bir yeri bulunmaktadır. Bu çalışma havzadaki geçmiş yıllardan günümüze kadar yağış ve akış eğiliminin ne yönde olacağını net biçimde verebilmektedir. $\mathrm{Y}=\mathrm{a}+\mathrm{b} * \mathrm{X}$ şeklindeki regresyon eşitliliğinde " $b$ " değeri ilişkideki doğrunun eğimini ifade etmektedir. Bu değer eğilim konusunda fikir verebilmektedir. Ancak istastistiksel güven düzeyleri arasında bir eğilimin var olup olmadığı Mann-Kendall Mertebe Korelasyonu Testi ile elde edilebilmektedir. Araştırmada her iki akım gözlem istasyonu ve yağış meteoroloji istasyonu için her ay ve mevsim için uzun dönemli trend analizleri gerçekleştirilmiştir.

\subsection{Yağış Verilerine Ait Mann-Kendall Mertebe Korelasyonu Testi Bulguları}

Yağış verileri için uzun dönemli olarak (2005-2014) gerçekleştirilen trend analizleri her ay ve mevsim için ayrı ayrı değerlendirilmiştir.

\subsection{Uzun Dönemli Yağış Verilerinin Trend Analizi}

Her bir ay için uzun dönemli yağış verileri (2005-2014) Mann-Kendall testine tabi tutulmuştur. Her bir aya ait eğilim grafiği, u (t) ve u’(t) grafiği ile Mann-Kendall sonuç tablosu Şekil 5 üzerinde gösterilmektedir.

Regresyon analizine göre oluşturulan eşitliklerdeki eğimlere ve eğilim düzlemlerinde bir artış ve azalış trendlerinin varlığı görülebilmektedir. Ancak bu varlığın istatistiksel açıdan önemi için \%95 güven aralık sınırları dahilinde yer alabilecek u(t) ve u'(t) grafikleri ile bunların sonuçlarına bakılması gerekmektedir. Yapılan MannKendall analizi eğrinin istatistiksel açıdan önemli olup olmadığını test etmektedir. Ancak hiçbir ayda u(t)'nin 1.96 değerine ulaştığı görülmemektedir. Dolayısıyla Mann-Kendallanalizi sonuçlarına göre uzun dönemli yağış verileri dikkate alındığında hiçbir ayda istatistiksel bakımdan anlamlı bir trend bulunamamıştır.

Her bir mevsim için uzun dönemli yağış verileri (2005-2014) Mann-Kendall testine tabi tutulmuştur. Ancak hiçbir mevsimde u(t)'nin 1.96 değerine ulaştığı görülmemektedir. Dolayısıyla Mann-Kendall analizi sonuçlarına göre uzun dönemli yağış verileri dikkate alındığında hiçbir mevsimde istatistiksel bakımdan anlamlı bir trend bulunamamıştır.

\subsection{Farklı Akım Gözlem İstasyonlarındaki Su Verimlerine Ait Mann-Kendall Mertebe Korelasyonu Testi Bulguları}

Akım gözlem istasyonlarından elde edilen debi değerlerinin su verimi (mm) ne dönüşümü gerçekleştirilerek uzun dönemli olarak (2005-2014) gerçekleştirilen trend analizleri her ay ve mevsim için ayrı ayrı değerlendirilmiştir.

\subsubsection{E17A020 (Hamam) Akım Gözlem İstasyonundaki Su Verimine Ait Trend Analizi}

E17A020 (Hamam) akım gözlem istasyonu için uzun dönemli su verimi değerleri (2005-2014) Mann-Kendall testine tabi tutulmuştur. Mann-Kendall analizi sonuçlarına göre uzun dönemli yağış verileri dikkate alındığında hiçbir ayda ve mevsimde istatistiksel bakımdan anlamlı bir trend bulunamamıştır. Diğer bir deyişle zaman serilerinde $\% 95$ güven aralığında artış veya azalış yoktur.

\subsubsection{E17A014 (Karahacılı) Akım Gözlem İstasyonundaki Su Verimine Ait Trend Analizi}

E17A014 (Karahacılı) akım gözlem istasyonu için uzun dönemli su verimi değerleri (2005-2014) Mann-Kendall testine tabi tutulmuştur. Her bir aya ve mevsime ait eğilim grafiği, u (t) ve u'(t) grafiği ile Mann-Kendall sonuç tabloları değerlendirilmiştir. Yapılan Mann-Kendall analizi sonuçlarına göre bazı aylarda u(t)'nin 1.96 değerine ulaştığı görülmektedir. Bu aylar Temmuz $(\mathrm{u}(\mathrm{t})=2.23)$ ve Eylül $(\mathrm{u}(\mathrm{t})=2.23)$ ayları olarak bulunmuştur. Bu aylarda \%95 güven düzeyinde bir artış trendinin varlığı saptanmıştır. Bu aylar dışında diğer aylar için istatistiksel bakımdan anlamlı bir trend bulunamamıştır. Diğer bir Temmuz ve Eylül ayları dışındaki zaman serilerinde $\% 95$ güven aralığında artış veya azalış yoktur. Ayrıca, yaz mevsiminde u(t)'nin 1.96 değerine ulaştığ görülmektedir $(\mathrm{u}(\mathrm{t})=2.05)$. Bu mevsimde \%95 güven düzeyinde bir artış trendinin varlığı saptanmıştır. Bu mevsim dışında 
diğer mevsimler için istatistiksel bakımdan anlamlı bir trend bulunamamıştır. Diğer bir Yaz mevsimi dışındaki zaman serilerinde \%95 güven aralığında artış veya azalış yoktur (Şekil 5).

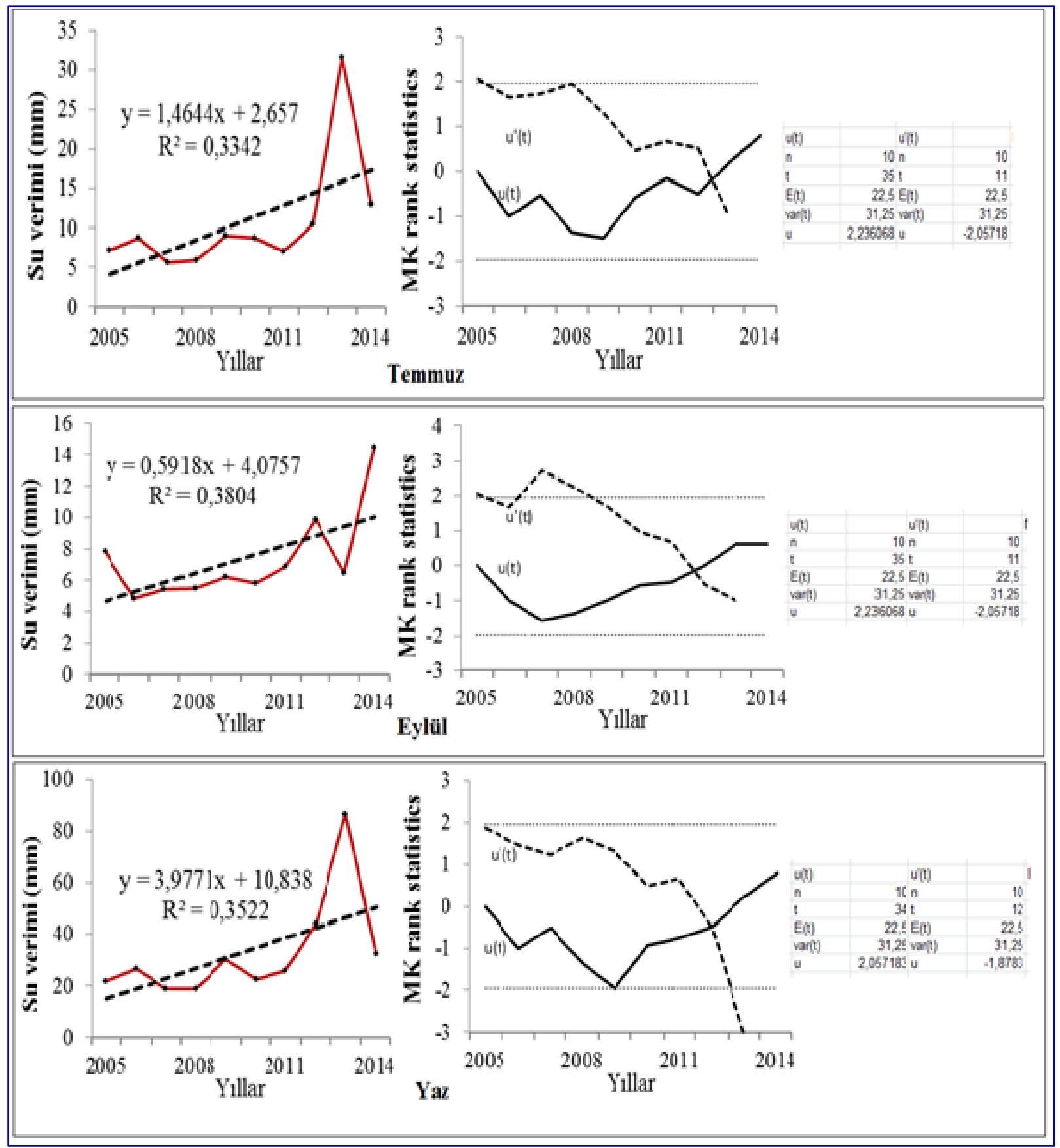

Şekil 5. E17A014 (Karahacılı) Akım Gözlem İstasyonuna ait su verimi (mm) değerlerinin Temmuz ayı, Eylül ayı ve Yaz mevsimi için uzun dönemli trend analizi sonuçları (sol şekiller: eğilim grafikleri, orta şekiller: $u(t)$ ve u'(t) grafikleri ve sağ tablolar: Mann-Kendall sonuç tabloları).

\subsubsection{Pettitt Testi Bulguları}

Araştırmada Pettitt testi \% 95 güven düzeyinde bir trendin var olduğu ay ve mevsimler için uygulanmıştır. Yağış ve E17A020 (Hamam) akım gözlem istasyonundan elde edilen su verimlerinde hiçbir ay ve mevsimde trend bulunamamıştır. E17A014 (Karahacılı) istasyonundan elde edilen uzun dönemli su verimi (mm) trendlerine bakıldığında aylık olarak Temmuz ve Eylül aylarında, mevsimlik olarak değerlendirilmesi koşulunda ise Yaz mevsiminde bir artış trendi belirlenmiştir. Pettitt testi ise trendin başlama noktasını belirlemede etkili bir istatistik yöntemdir. Pettitt testinin sonuçları aşağıda görülmektedir. 
Tablo 2: Pettitt testi sonuçları.

\begin{tabular}{lcccccc}
\hline \multicolumn{2}{c}{$\begin{array}{c}\text { E17A014 (Karahacılı) } \\
\text { Temmuz ayı }\end{array}$} & \multicolumn{2}{c}{$\begin{array}{c}\text { E17A014 (Karahacılı) } \\
\text { Eylül ayı }\end{array}$} & \multicolumn{2}{c}{$\begin{array}{c}\text { E17A014 (Karahacılı) } \\
\text { Yaz mevsimi }\end{array}$} \\
\cline { 1 - 4 } $\mathbf{t}$ & 7,9 & $\mathbf{t}$ & 7,1 & $\mathbf{t}$ & 7.4 \\
P değeri & $<0.0001$ & P değeri & $<0.0001$ & P değeri & $<0.0001$ \\
alfa & 0.05 & alfa & 0.05 & alfa & 0.05 \\
\hline
\end{tabular}

Tablo 2 deki " $\mathrm{t}$ ” değerleri trendin kırılma noktasını göstermektedir. Bu durum trendin başlangıç noktası olarak da ifade edilebilmektedir. 2005 yılının başlangıç yılı olarak kabul edilmesi koşuluyla E17A014 (Karahacılı) Temmuz ayı artış trendinin yaklaşık olarak 2013 yılında, E17A014 (Karahacılı) Eylül ayı artış trendinin yaklaşık olarak 2012 yılının başlarında ve E17A014 (Karahacılı) Yaz mevsimi artış trendinin ise 2012 yılının yaklaşık olarak yarısında kırılma noktasının gerçekleştiği belirlenmiştir. Dolayısıyla bu yıllardan itibaren trendlerde artış olduğu görülebilmektedir. Bu durum grafiksel olarak şekil 6 da gösterilmiştir.

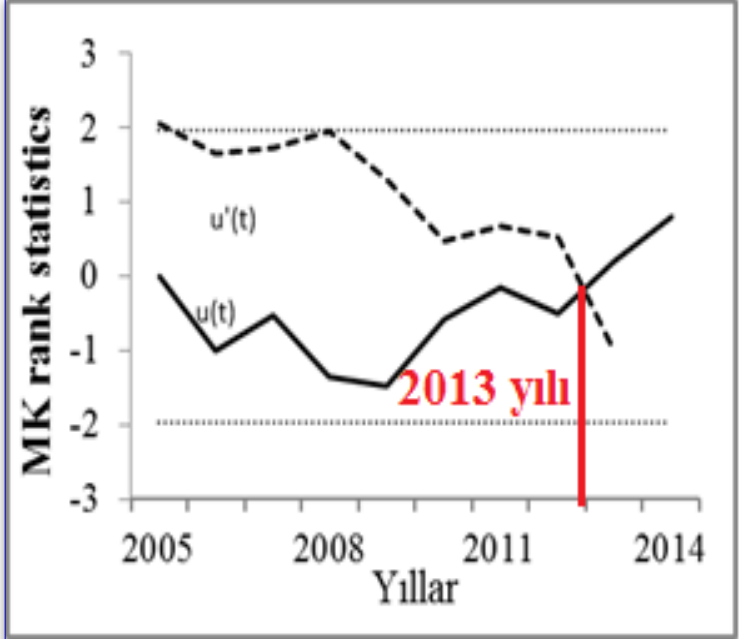

Temmuz ayı artış trendi

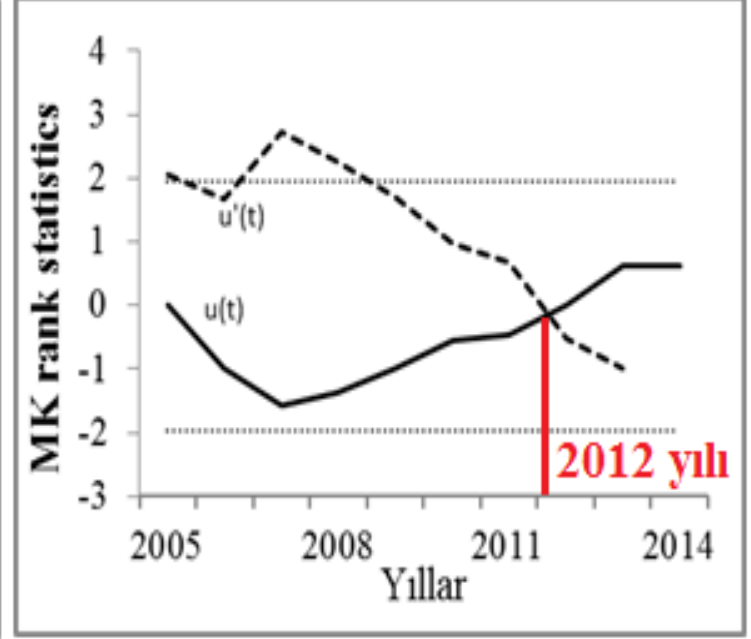

Eylül ayı artış trendi

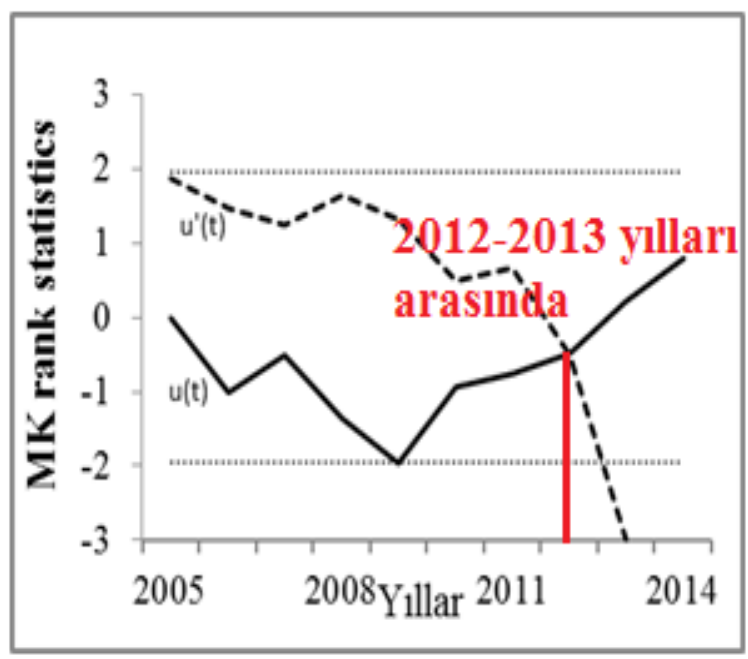

\section{Yaz mevsimi artıș trendi}

Şekil 6. E17A014 (Karahacılı) istasyonuna ait uzun dönemli su verimi (mm) değerlerinin Temmuz ve Eylül ayı artış trendleri ile Yaz mevsimi artış trendinin başlangıç noktasının Pettitt testi ile grafiksel biçimde gösterilişi. 
Grafiksel değerlendirmede Pettitt testi bulgularıyla $u(t)$ ve $u^{\prime}(t)$ eğrilerinin kesim noktalarının birbirleriyle uyumlu olduğu görülmektedir. Pettitt testi grafiksel değerlendirmeye göre avantajı ise trendin kırılma noktasının istatistiksel açıdan önemini de verebilmektedir.

\section{Sonuç ve Öneriler}

Yapılan araştırmada ülkemiz adına önemli bir su kaynağı konumunda bulunan Göksu nehri havzasının yağış ve akış ilişkileri değerlendirilmiştir. Yıllık bazda yapılan grafiksel değerlendirmeye göre özellikle 2008 yılına kadar her iki akım gözlem istasyonunun yıllık su verimi değerlerinin birbirine çok yakın bir eğilim seyrettikleri gözlemlenmiştir. Bu yıldan sonraki değişimler üzerinde yağış eğrisinin dikkate alınması gerekmektedir. Çünkü 2008 yılından sonra yağıştaki değişimlerin daha fazla olduğu ve bu yıldan sonra pik yağış değerlerine ulaşıldığ görülmektedir. Bu yağış değişimlerine her iki istasyonun da farklı biçimde hidrolojik reaksiyonlar (tepkiler) verdiği anlaşılmıştır. Su verimi değerlerindeki farklılaşma yağış miktarı dışında bu yılda ana akarsu ya da yan kollar üzerine yapılan baraj ve bentlerin de etkili olduğu düşünülmektedir. Çünkü baraj ve bend doğal akış koşullarını değiştirerek farklı biçimlerde akış ve su verimlerinin oluşabilmesine firsat vermektedir. Havzada yağış ve akış arasındaki kaybın büyük ölçüde buharlaşma ve suyun depolanmasından kaynaklanabildiği bilinmektedir. Barajlar hem suyu toplayarak havzaya düşen toplam suyun daha fazla buharlaşabilmesine olanak tanımakla beraber suyu tutarak akarsulardaki ölçümlerde doğal akış değerlerine göre farklı değerlerin oluşabilmesine firsat vermektedir. Göksu havzası özellikle tipik Akdeniz iklimi etkisi altında bulunması nedeniyle buharlaşmanın kuzeydeki diğer bölgelerimize göre daha fazla yaşanabileceği kaçınılmazdır. Bu durumda havzada ve havzaya özgü etkili bir su yönetimi planı hazırlanması gerekmektedir. Böyle bir planın hazırlanmasından önce mevcut durumun iyi bir biçimde analiz edilmesi gerekmektedir. Havzalar için akış katsayısı havzanın su üretme potansiyelini göstermesi bakımından önemli bir indikatör parametredir. Çünkü havzaya düşen yağışın ne kadarının akışa geçeceği bu parametre sayesinde yüzde biçiminde ifade edilebilmektedir. Araştırmada E17A020 (Hamam) akım gözlem istasyonuna ait akış katsayısı \% 43.49 olarak bulunmuştur. E17A014 (Karahacılı) istasyonunda ise bu değer \% 41.28 olarak elde edilmiştir. Ancak E17A014 (Karahacılı) istasyonu havzanın çıkış noktasına en yakın biçimde konumlanan akım gözlem istasyonudur. Bu nedenle havzanın tümünü temsil edebilecek yetenektedir. Dolayısıyla Göksu havzasının akış katsayısı \% 41.28 olarak kabul edilebilmektedir. Bu havza üzerine düşen 100 birimlik yağışın 41 biriminin akışa geçtiği bulunmuştur. Bu değer Akdeniz ikliminin etkisi altında bulunan bir havza için küçük bir rakam olarak kabul edilmemelidir. Ayrıca ülkemizin tüm havzaları dikkate alınarak geliştirilen akış katsayısı ise \% 37 dir (DSİ, 1999). Diğer bir deyişle Göksu havzasının akış katsayısı Türkiye ortalamasının üzerinde olduğu belirlenmiştir. Araştırmada Mevsimlik akış katsayısı değerleri de hesaplanmıştır. Özellikle yaz mevsiminde her iki akım gözlem istasyonunda da akış katsayısının \%100 ün üzerinde olması akarsuların özellikle bir su depolama alanından beslendiklerini göstermektedir. Çünkü yağış miktarı diğer mevsimlere göre yaz aylarında oldukça düşüktür. Bu düşüklük nedeniyle akarsu akışlarının da düşmesi gerekirken yağış miktarı üzerinde bir miktarda akması durumunu akarsuların belirli bir kaynaktan beslendiğini açıklamaktadır. Bu su depolama alanı toprak altı gibi doğal bir unsurla oluşabileceği gibi baraj ve bend gibi yapay unsurlarla da oluşabilmektedir. Toprak suyunun akarsuları doğrudan besleme yeteneği bulunmamaktadır. Ancak drenaj çizgisinin alçalıp yükselmesi ile toprak suyu akarsulara doğrudan etki edebilmektedir. Dolayısıyla akarsular üzerinde toprak suyu etkili olmakta fakat bu etkinin sınırlı kaldığı gözlemlenmektedir. Özellikle yaz mevsimindeki akış katsayısı yüksekliği havza içerisindeki kışın ve sonbaharda baraj ve bend gibi su depolama alanlarında biriktirilen suyun geç ilkbahar ve yaz mevsimlerinde tarım vb. amaçlarla akarsulara bırakılması nedeniyle oluştuğu düşünülmektedir. Bu durumda akarsuyun doğal akış özelliklerini kaybettiği de bir gerçektir.

2005-2014 yılları arasındaki değerler göz önüne alınarak yapılan analizlerde yağış verilerine ait herhangi bir trend bulunamamıştır. Aynı şekilde E17A020 (Hamam) akım gözlem istasyonunu göz önüne alınarak elde edilen su verimi $(\mathrm{mm})$ değerlerinde de hiçbir ay ve mevsimde bir trend elde edilememiştir. Ancak Göksu havzasını da temsil edecek nitelikte olan E17A014 (Karahacılı) istasyonunda Temmuz $(\mathrm{u}(\mathrm{t})=2.23)$ ve Eylül $(\mathrm{u}(\mathrm{t})=2.23)$ ayları ile Yaz mevsimindeki $(\mathrm{u}(\mathrm{t})=2.05)$ su verimlerinde istatistiki anlamda önemli bir artış trendi tespit edilmiştir. $\mathrm{Bu}$ artış trendinde özellikle son yıllarda yukarıda belirlenen baraj ve bend gibi depolama alanlarının etkisinin kuvvetli olduğu düşünülebilir. Yağış miktarı bu ay ve mevsimlerle birlikte hiçbir ay ve mevsimde artış trendi göstermemesi bu hiopotezi daha da güçlü hale getirmektedir.

Pettitt testi ise son yıllarda trendin başlangıç noktasının ya da kırılma noktasının bulunmasında sıklıkla kullanılan istatistiki bir test olarak karşımıza çıkmaktadır. Bu testte \%95 güven düzeyinde bir trendin varlığının belirlendiği E17A014 (Karahacılı) istasyonuna ait Temmuz ve Eylül ayları ile yaz mevsimi trendleri analiz edilmiştir. E17A014 (Karahacılı) Temmuz ayı artış trendinin yaklaşık olarak 2013 yılında, E17A014 (Karahacılı) Eylül ayı artış trendinin yaklaşık olarak 2012 yılının başlarında ve E17A014 (Karahacılı) Yaz 
mevsimi artış trendinin ise 2012 yılının yaklaşık olarak yarısında kırılma noktasının gerçekleştiği belirlenmiştir.

Araştırmanın nihai sonucu olarak havzada bölgesel ölçekte ve trend analizine göre bir iklim değişikliği bulgusuna rastlanılmamıştır. Yaz mevsiminde ve özellikle Temmuz ayı için görülen trend artışında yapay su depolama alanlarından akarsulara su beslenmesinin son yıllarda artış göstermesinin bir sonucu olduğu düşünülmektedir. Eylül ayı içerinde su verimindeki artışta yağış miktarının hiçbir ayda artış göstermemesi toprakların su depolama kapasitelerinin tamamen dolması sonucunda oluşan yüzeysel akış miktarlarında da son yıllarda artı̧̧ görülmesinin de etkisi olabilmektedir. Ancak bu durum yukarıda belirtildiği gibi akarsular üzerinde doğrudan etkili olan bir unsur olarak görülmemektedir. Tüm bu durumlar havzaya özgü su yönetimi planlarının oluşturulması ve uygulanmasının su kaynaklarının sürdürülebilirliğini artırmada önemli bir araç konumunda olacağı unutulmamalıdır.

\section{Açıklama}

Bu makalenin Abstract bölümü International Symposium on New Horizons in Forestry (ISFOR 2017) adlı sempozyumda yayınlanmıştır.

\section{Kaynaklar}

1. Arnell, N. W. (1999). Climate change and global water resources. Global Environmental Change, 9, S31S49.

2. Balcı, A. N. (1996). Toprak koruması. İstanbul Üniversitesi, İstanbul.

3. Babalık, A. A., Yazıcı, N., Dursun, İ. (2018). İklim Değişikliği, Kuraklık ve Türkiye. Uluslararası Su ve Çevre Kongresi (SUÇEV-2018), Bildiriler Kitab1, ISBN: 978-605-68414-1-5, 22-24 Mart 2018, p. 2337, Bursa, Türkiye.

4. Black, R., Bennett, S. R., Thomas, S. M., Beddington, J. R. (2011). Climate change: Migration as adaptation. Nature, 478(7370), 447-449.

5. Canadell, J. G., Raupach, M. R. (2008). Managing forests for climate change mitigation. Science, 320 (5882), 1456-1457.

6. DSİ (1999). Haritalı İstatistik Bülteni, Ankara.

7. Hurrell, J. W. (1995). Decadal trends in the North Atlantic Oscillation: regional temperatures and precipitation. Science, 269 (5224), 676-679.

8. Manabe, S., Wetherald, R. T. (1980). On the distribution of climate change resulting from an increase in $\mathrm{CO}_{2}$ content of the atmosphere. Journal of the Atmospheric Sciences, 37(1), 99-118.

9. Meinshausen, M., Meinshausen, N., Hare, W., Raper, S. C., Frieler, K., Knutti, R., Frame, D.J., Allen, M. R. (2009). Greenhouse-gas emission targets for limiting global warming to 2 C. Nature. 458(7242): 1158-1162.

10. Nijssen, B., O'Donnell, G. M., Hamlet, A. F., Lettenmaier, D. P. (2001). Hydrologic sensitivity of global rivers to climate change. Climatic change, 50(1-2), 143-175.

11. Odum, E. P., Barrett, G. W. (1971). Fundamentals of ecology(Vol. 3). Philadelphia: Saunders.

12. Özhan, S. (2004). Havza amenajmanı. İÜ Orman Fakültesi yayın, (481).

13. Pettitt, A. N. (1979). A Non-Parametric Approach to the Change-Point Detection, Applied Statistics, Cilt 28, s.126-135.

14. Rustad, L. E., Huntington, T. G., Boone, R. D. (2000). Controls on soil respiration: implications for climate change. Biogeochemistry, 48(1), 1-6.

15. Stringer, L. C., Dyer, J. C., Reed, M. S., Dougill, A. J., Twyman, C., Mkwambisi, D. (2009). Adaptations to climate change, drought and desertification: local insight stoenhance policy in southern Africa. Environmental Science \& Policy, 12(7), 748-765.

16. Schipper, L., Pelling, M. (2006). Disaster risk, climate change and international development: scope for, and challenges to integration. Disasters, 30(1), 19-38.

17. Spittlehouse, D. L., Stewart, R. B. (2003). Adaptation to climate change in forest management. Journal of Ecosystems and Management, 4(1):1-11. 
18. Sneyers, R. (1990). On The Statistical Analysis of Series of Observations. WMO Technical Note 143. p. 192. Genova.

19. Toros, H. (2012). Spatio-temporal variation of Daily extreme temperatures over Turkey. International Journal of Climatology. 32(7): 1047-1055.

20. Yurtseven, İ., Serengil, Y. (2016). İstanbul ilinde mevsimsel toplam yağışların değişimleri ve eğilimleri. Ístanbul Üniversitesi Orman Fakültesi Dergisi, 67(1): 1-12. 